\title{
Synthesis and Characterization of ZnO Film on Stainless Steel Wire and Bioaerosol Antimicrobial Activity
} Evaluation

\author{
Alfonso Espitia Cabrera ${ }^{1}$, Jose Luis Contreras Larios ${ }^{1}$, IlyaEspitia-Cabrera ${ }^{2}$, Ma-Teresa Nunez Cardona ${ }^{3}$, Doris \\ Neri Cortes ${ }^{4}$ and Luis Raul Tovar Galvez ${ }^{5}$ \\ 1. Energy Department, Metropolitan Autonomous University, Azcapotzalco 02200, Mexico \\ 2. Chemical Engineering School, Michoacan University of San Nicolas of Hidalgo, Morelia 58030, Mexico \\ 3. Man and Its Environment Department, Metropolitan Autonomous University, Xochimilco 04960, Mexico \\ 4. Biochemistry Department, Biological Sciences National School, National Polytechnic Institute, Mexico D.F. 07738, Mexico \\ 5. Interdisciplinary Centre of Research and Studies on Environment and Development, National Polytechnic Institute, Mexico D.F. \\ 07340, Mexico
}

\begin{abstract}
ZnO}$ thin films were prepared by electrophoretic deposition on stainless steel wire sieve, using zinc acetate as a precursor. The film was sintered and characterised by Scanning Electron Microscopy (SEM), X-Ray Diffraction (XRD) and chemisorption of oxygen. A culture bacterial consortium composed by gram negative rod-shaped microbes was prepared in a liquid agar in a flask. It was transported by air through a reactor equipped with a UV lamp with 3 and 5 sieves of a stainless steel wire coated with $\mathrm{ZnO}$ film. It was exposed in continuous in five experiments to photocatalytic advanced oxidation. The experiments showed a total efficiency for colony forming unit reduction of a maximum of $99.66 \%$ for a residence time of 20 seconds with 5 stainless steel wire where exposed in continuous to UV. Also they were evaluated at 7.5 seconds, observing that the contribution of residence time and amount of catalytic for the CFU reduction was quite similar. Variance analysis showed that the efficiency was significant with the no parametric Kruskal-Wallis test with $\mathrm{P}<0.05$. This technology could be used to clean indoor air of closed environments such as hospitals, crowded buildings or public transportation systems where airborne bacteria has been documented.
\end{abstract}

Key words: Photocatalytic oxidation, $\mathrm{ZnO}$ thin film, antibacterial activity, $\mathrm{ZnO}$ film on stainless steel wire.

\section{Introduction}

The study of $\mathrm{ZnO}$ has acquired great importance because of its antimicrobial and bactericidal properties and potential to eliminate microorganisms through photocatalytic oxidation when $\mathrm{ZnO}$ is irradiated with ultraviolet light in the presence of water and oxygen [1-3]. The $\mathrm{ZnO}$ has shown a multifunctional inorganic particle with antimicrobial properties [4].

$\mathrm{ZnO}$ has been recognized as a preferable material for a variety of environmental applications due to its high photosensitivity, non-toxic nature, low cost and

Corresponding author: Alfonso Espitia Cabrera, master, research fields: air pollution and wastewater control. E-mail: alfonso.espitiac@gmail.com. chemical stability [5]. $\mathrm{ZnO}$ is a wide band gap semiconductor, and is considered as suitable alternative to $\mathrm{TiO}_{2}$ due to its non-toxicity and relatively lower preparation cost [3].

$\mathrm{ZnO}$ has a high UV absorptivity and can absorb more light in the UV spectrum than $\mathrm{TiO}_{2}$ semiconductors [6], which has higher photocatalytic activity than titanium dioxide [7], and possesses superior durability, and heatresistance [8].

$\mathrm{ZnO}$ has been investigated for its qualities as an antibacterial agent in the absence of light since as early as the 1950s, and has since been shown to be effective for the inactivation of Escherichia coli, Salmonella typhimurium, Bacillus subtilis and 
Staphylococcus aureus among others [9].

Nanocomposites of $\mathrm{ZnO} / \mathrm{Fe}_{3} \mathrm{O}_{4}$ were tested against Staphylococcus aureus and Escherichia coli and the antibacterial activity of these nanoparticles was found to be dependent on the weight ratio $(\mathrm{Zn}) /(\mathrm{Fe})$, the higher the ratio, the higher the antibacterial activity [10], while for nanocomposites of $\mathrm{ZnO} / \mathrm{ZnAl}_{2} \mathrm{O}$ tested against Escherichia coli, the inactivation rate increases with time [5].

$\mathrm{ZnO}$ with ultraviolet light irradiation, in the presence of water and oxygen, overcomes the band gap between the Valence Band (VB) and Conduction Band $(\mathrm{CB})$. This generates the electron $\left(\mathrm{e}^{-1}\right)$ hole $\left(\mathrm{h}^{+}\right)$ pairs which react with $\mathrm{O}_{2}$ and $\mathrm{H}_{2} \mathrm{O}$ to form superoxide anion radicals in the cathodic sites $\left(\mathrm{O}_{2}\right)$, and radicals $(\mathrm{OH})$ at the anodic sites. This leads to the production of other reactive species such as hydrogen peroxide. These oxidative species $\left(\mathrm{h}^{+}, \mathrm{OH}, \mathrm{O}_{2}\right.$ and $\left.\mathrm{H}_{2} \mathrm{O}_{2}\right)$ are highly reactive, and considered to be the dominant oxidative species contributing to the mineralisation of microorganisms [9]. The oxidation is initiated by the attraction of oxidisable material to the semiconductor $\mathrm{ZnO}$ surface, where the charge of the pair-hole is transferred to the adsorbed species [11] and the $\mathrm{OH}$ is oxidised to $\mathrm{CO}_{2}$ and $\mathrm{H}_{2} \mathrm{O}$ [12]. The effect of the photocatalytic oxidation on the bacteria was evaluated by monitoring cell cultivability, cell wall integrity and nucleic acid stability [13].

There have been several bactericidal mechanisms proposed, one of which stated that the sorption of ions onto the negatively charged bacterial cell wall causes deactivation of cellular enzymes, and the disruption of membrane permeability, leading to eventual cell lysis and death. Also, the interaction of reactive species with enzymes in the respiratory chain reaction results in the uncoupling of respiration from the synthesis of ATP and oxidation of the intracellular Coenzyme A (CoA), which inhibitscell respiration and subsequently causes cell death $[9,13]$. Peroxidation of the lipidmembrane and the eventual oxidation on the membrane proteins will cause a rapid leakage of potassium ions from the bacterial cell resulting in direct reduction of cell viability [14].

As a consequence of disorder in the cell wall permeability, drainage of the intracellular constituents and alterations of the protein structure occur [15], also, electrostatic interactions within the cytoplasmic membrane of the cell wall, breaks the lipid bilayer of bacterium and fungus, draining the cytoplasm content [13]. Most of the research indicates that the destruction of the cell membrane that protects the cytoplasm is an important process for inactivation [16].

Air polluted by microorganisms in closed are as such as buildings and hospitals can affect the health and welfare of exposed individuals [17, 18]. Bacillus is a typical bacteria that is viable in the air; this genus has been isolated from external air as the predominant microorganism in Oregon in rural and urban environment and Beijing [19], and as the predominant microorganism in indoor air in an Indian hospital, reported as Gram Negative Bacillus (GNB) [20]. Microorganisms carried in indoor atmospheres are a public health problem [21-23]. In the past, this problem has been treated using UV light, promoting the formation of dimmers or double molecules of the nucleotides cytosine-cytosine, thymine-thymine, cytosine-thymine and uracil-uracil, thus, inhibiting the replication of DNA and RNA and limiting reproduction of the microorganism [24]. However, UV-induced processes suffer from a lack of residual effect as the chlorine [9].

Related to the support materials to photocatalytic reaction, AISE 304 steel and wire mesh-supported materials have recently been used as monolithic catalysts for different reactions such as the photo degradation of methylene blue solutions under ultraviolet irradiation [25, 26]. Also SS 304 steel sieves 100 meshes and 300 meshes coated with $\mathrm{TiO}_{2}$ thin films deposited by sol-gel and dipping methods have been used to deactivate airborne microbialcells [27].

In order to design the experiment, it was considered 
that the photocatalytic oxidation reaction performance is a function of the source light wavelength and intensity, the reaction surface or photocatalyst amount, the concentration of bacteria (Colony Forming Units), humidity, temperature, oxygen and residence time as the most important $[28,29]$.

The novelty of this work is the application of electrophoretic deposition of zinc oxide to achieve uniform films of $\mathrm{ZnO}$ on a Stainless Steel (SS) 304 US 100 wire sieve. This film is then irradiated with UV light to degrade airborne bacteria by continual photocatalytic oxidation in a one litre reactor. The degradation efficiency as a function of time and amount of photocatalyst, once deducted the degradation caused by the UV light alone was evaluated. The results hypothetically expected were a significant reduction in the Colony Forming Units (CFU).

This technology could be used to clean indoor air of closed environments such as hospitals, crowded buildings or public transportation systems [18], where the presence of airborne bacteria has been documented as a problem $[30,31]$ and has been considered a factor responsible for inducing sick building syndrome [13, 32].

\section{Material and Methods}

\subsection{Preparation of Substrate}

The SS 304 US 100 wire mesh sieve substrates were prepared by removing all of the impurities with an abrasive paper, cutting the wire sieve into circles of $7.5 \mathrm{~cm}$ of diameter with a hole of $2.5 \mathrm{~cm}$ in order that they could be inserted into a quartz tube of $2.5 \mathrm{~cm}$ of diameter.

The wire sieves were ultrasonically cleaned in acetone by two hours and rinsed with deionized water.

\subsection{Preparation of Thin Film Coating}

A stainless steel 304 wire sieve was exposed in an electrodeposition cell to a solution of $0.004 \mathrm{M}$ of zinc acetate $\mathrm{Zn}\left(\mathrm{CH}_{3} \mathrm{COO}\right)_{2} \cdot 2 \mathrm{H}_{2} \mathrm{O}$ with a purity of $>97 \%$ and a MW of $219.53 \mathrm{~g} / \mathrm{mol}$, the latter was dissolved in distilled water. The electrodeposition cell was comprised of a Nalgene jar (Fig. 1), with a zinc acetate solution where the SS wire sieve was coated with $\mathrm{Zn}(\mathrm{OH})_{2}$ using a galvanic source MR PG-3VE with 20 Volts for 2 minutes. In the cell, the stainless steel wire sieve was the cathode and a stainless steel plate was the anode; a constant voltage was applied between the two electrodes (Fig. 2).

\subsection{Thermal Treatment of $\mathrm{Zn}(\mathrm{OH})_{2}$}

The $\mathrm{ZnO}$ films obtained were calcined from room temperature to $500{ }^{\circ} \mathrm{C}$ with a heating rate of $10{ }^{\circ} \mathrm{C} / \mathrm{min}$ and maintained at this temperature for 2 hours in order to obtain the $\mathrm{ZnO}$, before being cooled in an oven.

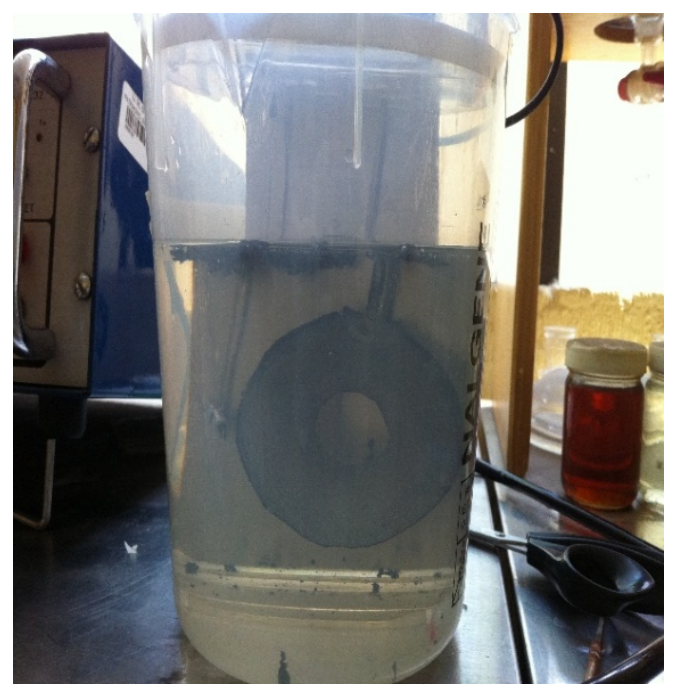

Fig. 1 Electrodeposition cell.

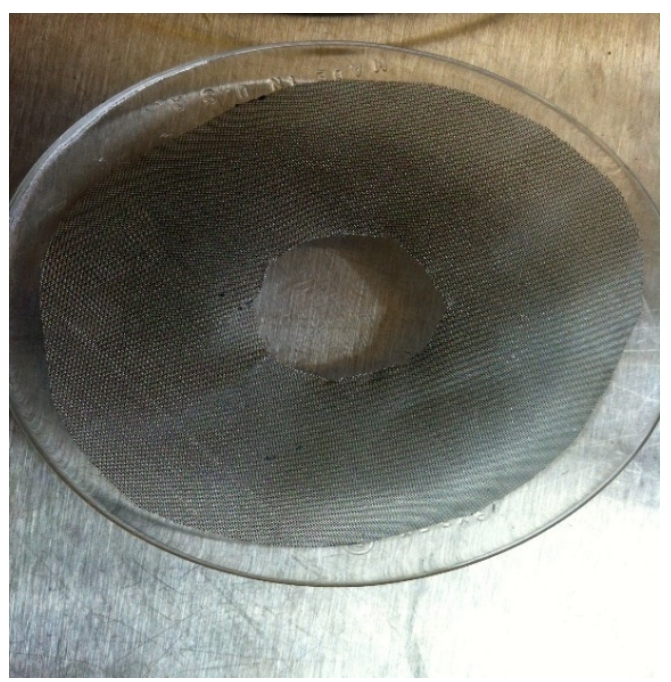

Fig. 2 Substrate coated with ZnO. 
The agglomerates gels formed in the electrodeposition process and not attached to the cathode, remain suspended in the solution of zinc acetate in the electrodeposition cell. They were filtered and calcined at $500{ }^{\circ} \mathrm{C}$, and then characterized by SEM and XRD to verify that it was obtained $\mathrm{ZnO}$, and by chemisorption to measure active sites.

\subsection{Chemisorption of Oxygen}

The volumetric apparatus (Fig. 3) containing: a cell of known volume made of stainless steel, two digital sensors of low and high pressure and a high vacuum system and furnace for pretreatment of samples were used.

These samples were heated to $300{ }^{\circ} \mathrm{C}$ for $2 \mathrm{~h}$ under high vacuum $\left(1 \times 10^{-3}\right.$ torr $)$ to remove the adsorbed gases. The oxygen used in the chemisorption was of high purity $99.99 \%$ (Infra). Once the sample was at $25{ }^{\circ} \mathrm{C}$, an injection of $\mathrm{O}_{2}$ (589 torr) was made and allowed to stabilize for $4 \mathrm{~h}$ to occur the $\mathrm{O}_{2}$-chemisorption-physisorption, then vacuum $(1 \times$ $10^{-3}$ torr) was applied for $10 \mathrm{~min}$ and again 589 torr of $\mathrm{O}_{2}$ were injected to know the $\mathrm{O}_{2}$ physisorption. The difference between these two adsorption isotherms allowed to determine the amount of $\mathrm{O}_{2}$ chemisorbed.

\subsection{Scanning Electron Microscopy}

The coating morphology and composition of ten samples were analysed by Scanning Electron Microscopy (SEM) with a SEM SUPRA 55VP instrument (Zeiss). It was a high resolution SEM that used a Schottky-type field-emission electron source. A beam booster was used to optimise electron optical performance at all accelerating voltages. The optical column had no crossovers and utilised a magnetic/electrostatic objective lens to minimise beam imperfections at low voltage by reducing the chromatic aberration. The qualitative and quantitative chemical analyses were obtained by coupling the energy dispersive spectroscopy of X-ray (EDS) to microscope.

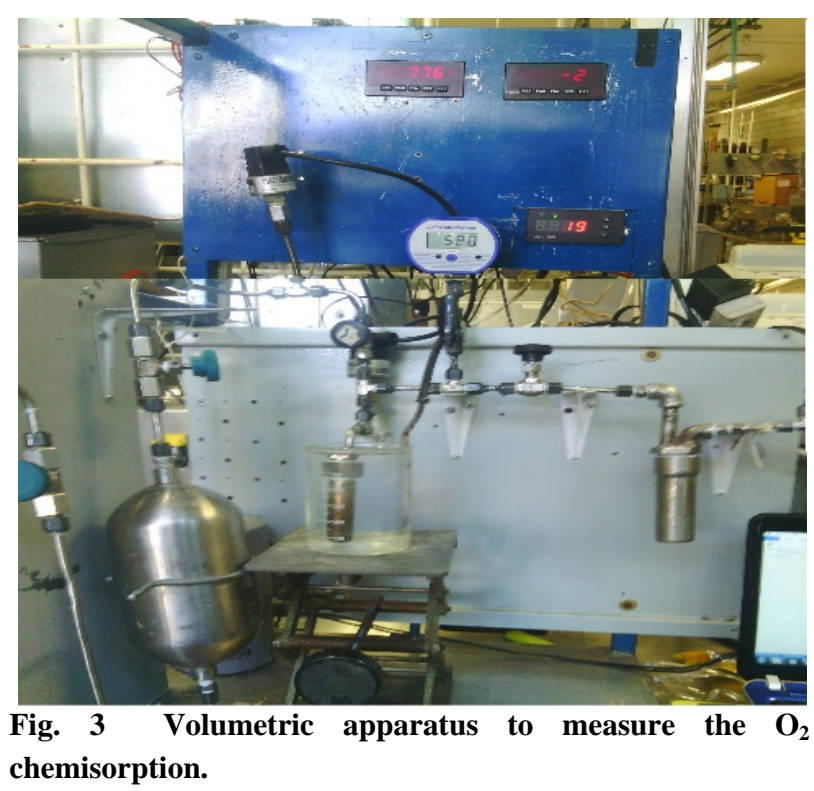

\subsection{X-Ray Diffraction}

An X-ray D-500 Siemens diffractometer equipped with a copper anode tube source, which generates a $\mathrm{Cu}$ radiation with a $\mathrm{K} \alpha(\lambda=1.54 \times 18 \AA)$, comparable to the spacing among atoms. The beam is collimated (forced into parallel rays), shaped (so that it has a definite "shadow") and directed onto the sample, which is in the form of a flat plane, taking advantage of Bragg-Brentano geometry: the entire sample diffracts the beam toward the same detector, enabling a larger sample and a larger beam size to be used as copper tube and a nickel filter. The diffractometer can identify crystalline compounds by matching diffraction patterns to a database.

\subsection{Culture Preparation}

A bacteria culture consortium was prepared, using microbial strains cultivated from viable native bacteria from air samples, collected from the atmosphere in a station of the atmospheric monitoring network from the Mexico State in the border of Mexico city. The bacteria were rod-shaped and showed a negative response to Gram staining. Nutrient broth was used to induce massive growth of these bacteria, which were incubated at room temperature for 48 hours and stored in a one litre vacuum flask. 


\subsection{Photoreactor}

A cylindrical reactor with a one litre of capacity was adapted to carry out the photocatalytic reaction. It comprised a container with a germicide UV lamp light source, Light Source Inc. model GPH254T5L/4 MI-50-93, (254 nm wavelength), protected with a quartz tube that support inserted three or five stainless steel 304 wire sieves, covered with $\mathrm{ZnO}$.

The reactor was equipped with two sampling ports to sampling before and after the photocatalytic reaction. It was integrated in a train consisting of the vacuum flask attached to the reactor joined to two flasks in series with acidulated water $(0.1 \mathrm{M}$ sulphuric acid). This destroys any bacteria that were not inactivated in the reactor before the final outlet, through the pump that extracted the microbes from the vacuum flask (Fig. 4). The sieves were inserted into the quartz tube to be irradiated directly on the reaction surface (Fig. 5) passing the airborne bacterial through them.

\subsection{Bacteria Degradation}

The photocatalytic oxidation was a continuous process, where the following parameters were maintained constant: humidity at $30 \%$, UV wavelength of $254 \mathrm{~nm}$ and intensity of $2.9 \mathrm{mWs} / \mathrm{cm}^{2}$ and temperature of $26^{\circ} \mathrm{C}$.

The variables studied were the surface reaction area and the residence time.

In the experiment, the bacterial consortium was carried out from the vacuum flask through the reactor with a vacuum pump (Emerson model S3MYHCB-1452), where samples of $100 \mathrm{~cm}^{3}$ of air were extracted with a syringe at the entrance and at the reactor outlet through the sampling ports. These samples were injected into a Petri dish containing a standard liquid culture medium, using an impactor equipped with a diffusion plate, where the samples were retained for 5 minutes. The Petri dishes containing the bacterial consortium were incubated for $48 \mathrm{~h}$ and the CFU in the samples were analysed.

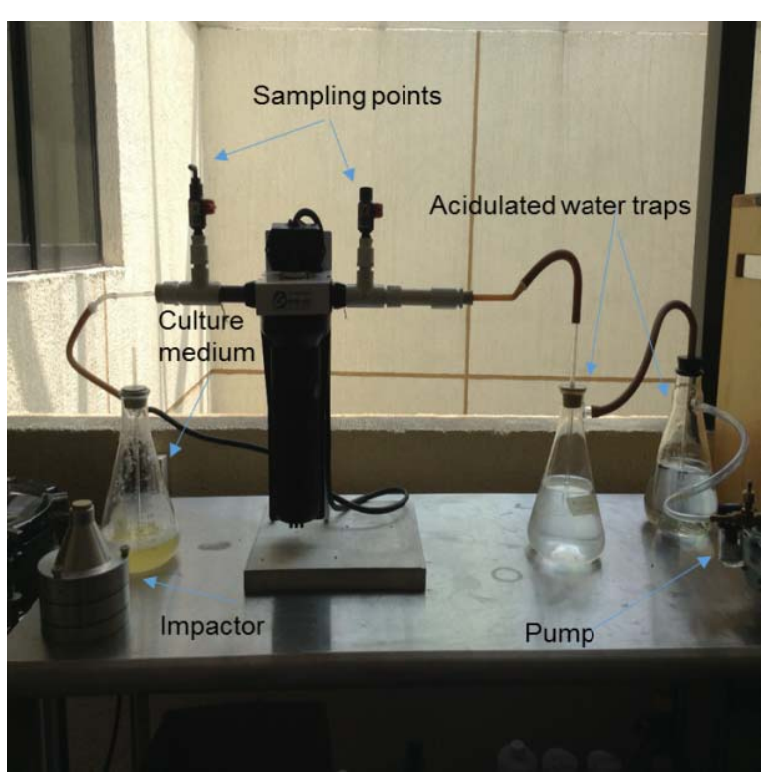

Fig. 4 Reactor train arrangement.

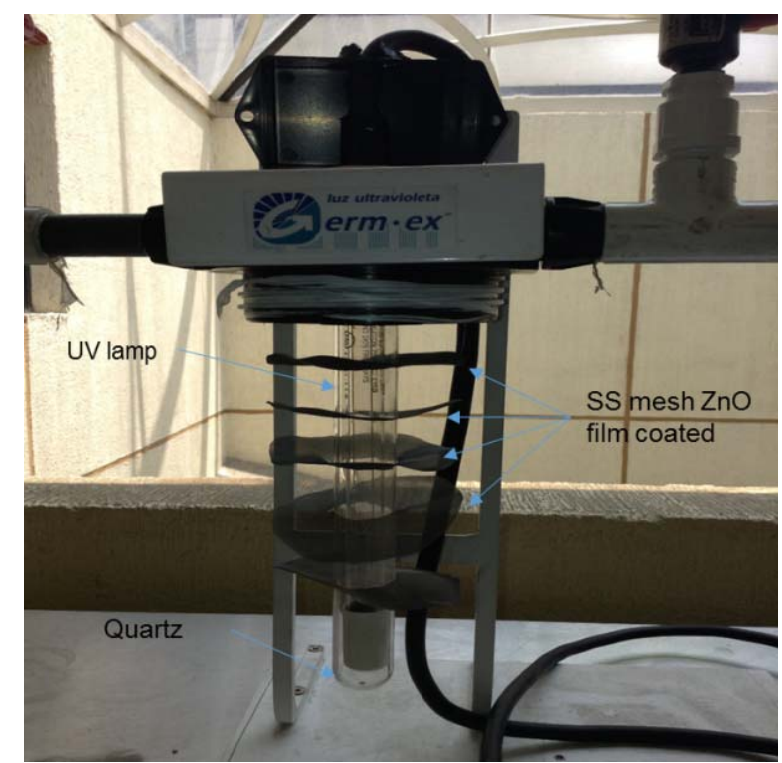

Fig. 5 Reactor interior view.

The experiments were conducted five times with different residence time of 7.5 seconds and 20 seconds and with three and five coated films, having $120 \mathrm{~cm}^{2}$ of surface reaction/ $1,000 \mathrm{~cm}^{3}$ of volume and $200 \mathrm{~cm}^{2}$ surface reaction $/ 1,000 \mathrm{~cm}^{3}$ of volume respectively, which inserted to observe the effect of the amount of photocatalytic material and residence times on the reduction of CFU (Table 2). In order to eliminate the effect of ultraviolet light on bacterial degradation, it was also evaluated this condition, taking five samples at the inlet and outlet of the reactor. 


\section{Results and Discussion}

\subsection{Scanning Electron Microscopy}

The presence of the film on the network was observed by identifying the $\mathrm{ZnO}$ as well as its composition by EDS. Micrographs are presented at low magnification $50 \mathrm{X}$ and at 40,000 X in Figs. 6 and 7. In these images, it is possible to observe the nanostructure of the $\mathrm{ZnO}$ film. The elemental composition of the film and the SS-wire sieve is shown in Fig. 8. An average composition of $2.52 \mathrm{wt} \%$ of $\mathrm{Zn}$ was obtained. This means that $3.13 \mathrm{wt} \%$ of $\mathrm{ZnO}$ was present. The presence of $\mathrm{Fe}(61.72 \mathrm{wt} \%), \mathrm{Cr}$ (15.46 wt \%), Oxygen (11.02 wt \%), Ni (6.92 wt \%), Mn (1.66 wt \%) and C (0.66 wt\%) were also observed.

The films obtained were homogeneous as others recently reported on stainless steel sieves with surface coated $\mathrm{TiO}_{2}$ thin films to degrade bacteria with similar efficiencies [26].

The SS wire sieve from the second experiment M2, had the elemental composition shown in Fig. 8 in percent of weight obtained with the SEM SUPRA 55VP Bruker Nano GMBH instrument, whereas the other samples had similar compositions.

\subsection{X-Ray Diffraction}

The XRD confirmed the presence of crystal of $\mathrm{ZnO}$ on samples obtained from several SS-wire $<$ sieves. Fig. 9 shows the X-ray analysis pattern of a sample of $\mathrm{ZnO}$ powder as zincite obtained from the agglomerate gel filtered and calcined at $500{ }^{\circ} \mathrm{C}$ and reported as the zincite phase, as previously described [33]. Fig. 9 also shows a sample representative of the X-ray pattern of the $\mathrm{ZnO}$ electrodeposited on the SS as a film, where $\mathrm{ZnO}$ was in the hexagonal zincite phase. The sample showed the $\mathrm{Zn}$ and Fe (austenite) together with $\mathrm{Zn}$ and $\mathrm{ZnO}$ reflexions.

\subsection{Chemisorption of Oxygen}

In average, the amount of $\mathrm{ZnO}$ deposited on the sieve surface was of $0.000135 \mathrm{~g} / \mathrm{cm}^{2}$ of sieve. The $\mathrm{O}_{2}$

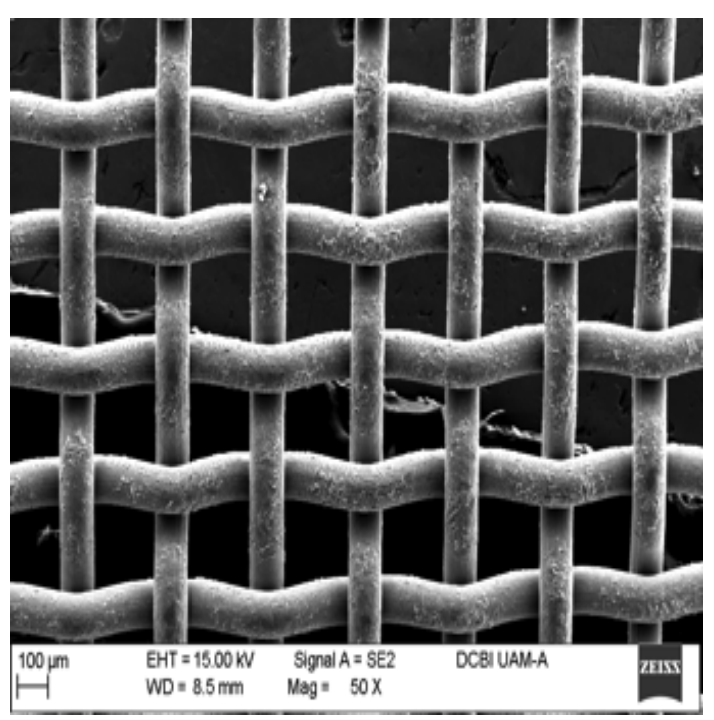

Fig. 6 SEM image of the SS wire sieve covered with $\mathrm{ZnO}$ $50 \mathrm{X}$ magnification.

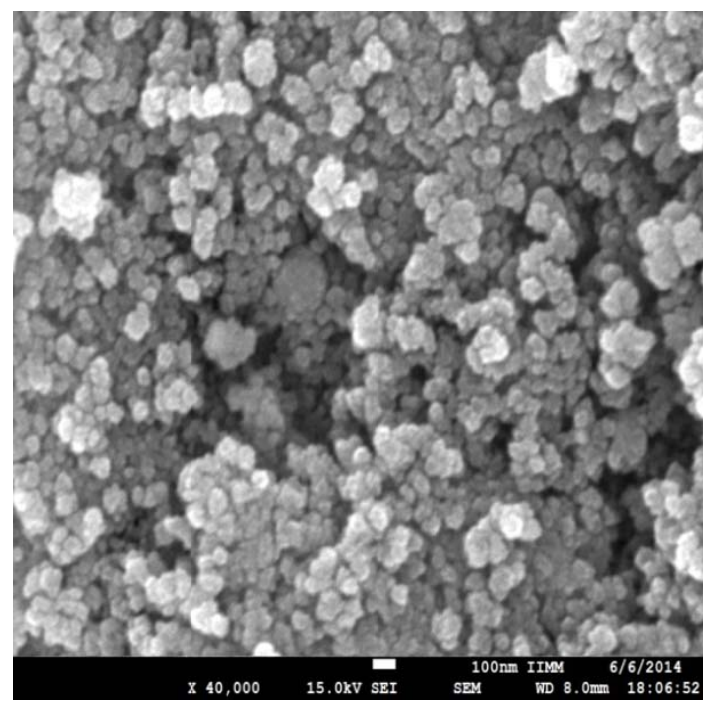

Fig. 7 SEM image of the SS wire sieve covered with $\mathrm{ZnO}$ 40,000 X magnification.

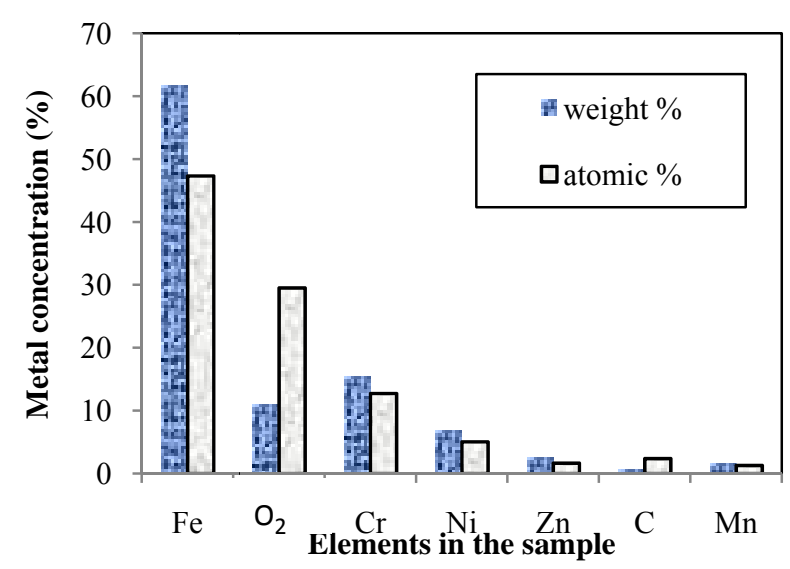

Fig. 8 Composition of the SS wire sieve by EDS. 


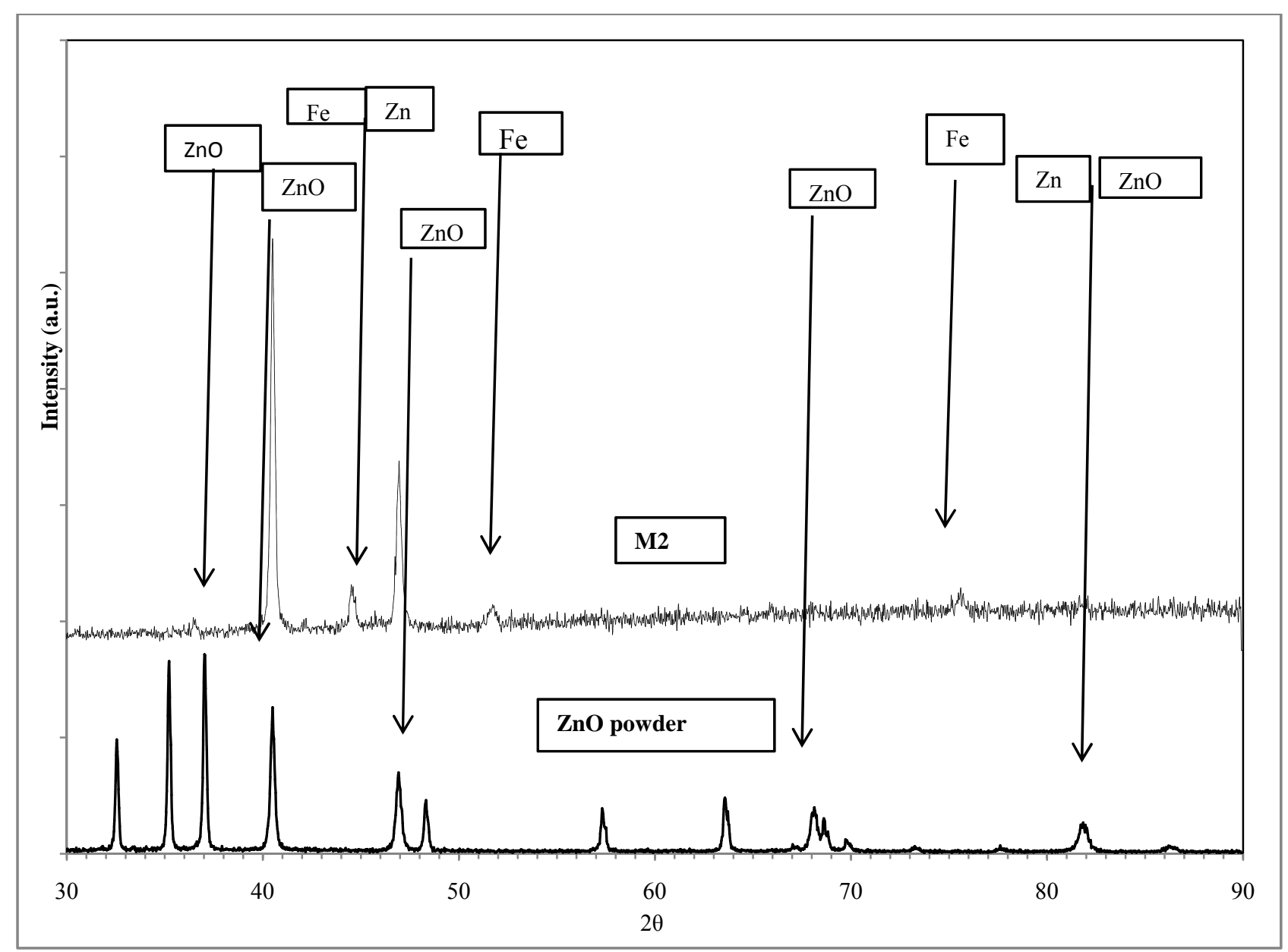

Fig. $9 \mathrm{X}$-ray of $\mathrm{ZnO}$ powder as zincite and $\mathrm{ZnO}$ supported on SS wire sieve.

isotherm of the SS-wire sieve showed very low $\mathrm{O}_{2}$ chemisorption (Fig. 10 and Table 1) while the $\mathrm{ZnO}$ powder showed a typical $\mathrm{O}_{2}$ isotherm (Fig. 12). The sample $\mathrm{M} 2$ of $\mathrm{ZnO}$ on SS-wire sieve showed an $\mathrm{O}_{2}$ chemisorption larger than the $\mathrm{O}_{2}$ chemisorption of the $\mathrm{ZnO}$ powder. This result shows that the $\mathrm{ZnO}$ film supported on the wire sieve had more vacancies $\mathrm{O}_{2}$ on its surface after $\mathrm{H}_{2}$ reduction process than the $\mathrm{ZnO}$ powder.

\subsection{Photocatalytic Activity}

The photocatalytic activity was determined as a function of the bacterial $\mathrm{CFU}$ reduction. Table 2 shows the efficiency of destruction when the airborne bacterial were exposed to UV alone as well as the efficiency with UV and SS wire sieves coated with the $\mathrm{ZnO}$ film. Table 3 shows the efficiency increment with residence time and amount of photocatalyst.

The data shows, that when the amount of photocatalytic material increment, the CFU reduction is slightly more than when the residence time increment, and that the CFU reduction tends to $100 \%$ when both parameters are incremented.

\subsection{Variance Analysis}

With these data, it was carried out a variance analysis to establish the significance of the experiment, with the hypothesis that the two experiments are different and that the differences are significant, as an alternative hypothesis, it was proposed that the experiments are not different.

Applying the Shapiro-Wilk test, it was confirmed that the data do not follow a normal distribution with a Probability value $\leq 0.001$ (Table 4). 

Antimicrobial Activity Evaluation

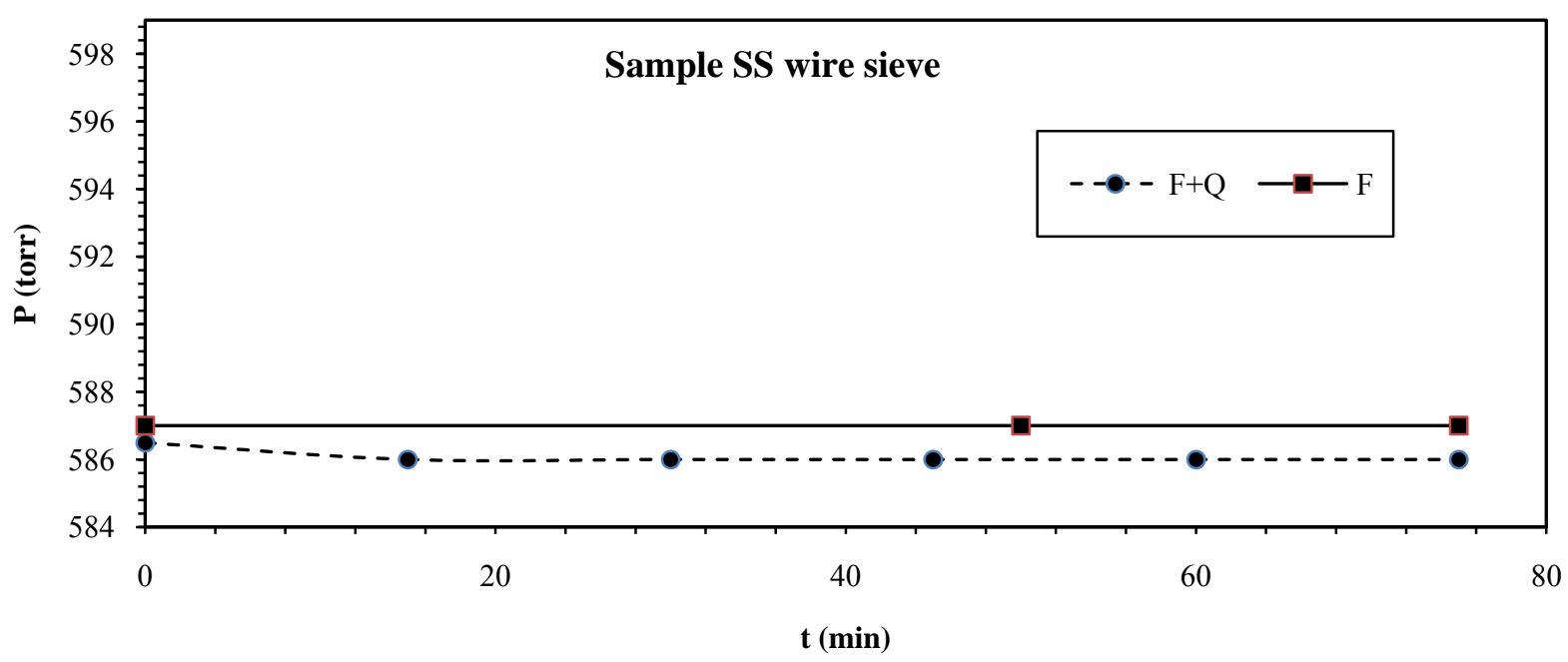

Fig. $10 \mathrm{O}_{2}$ isotherm of the SS-wire sieve at $25^{\circ} \mathrm{C}$, chemisorption + physisorption $(\mathrm{F}+\mathrm{Q})$.

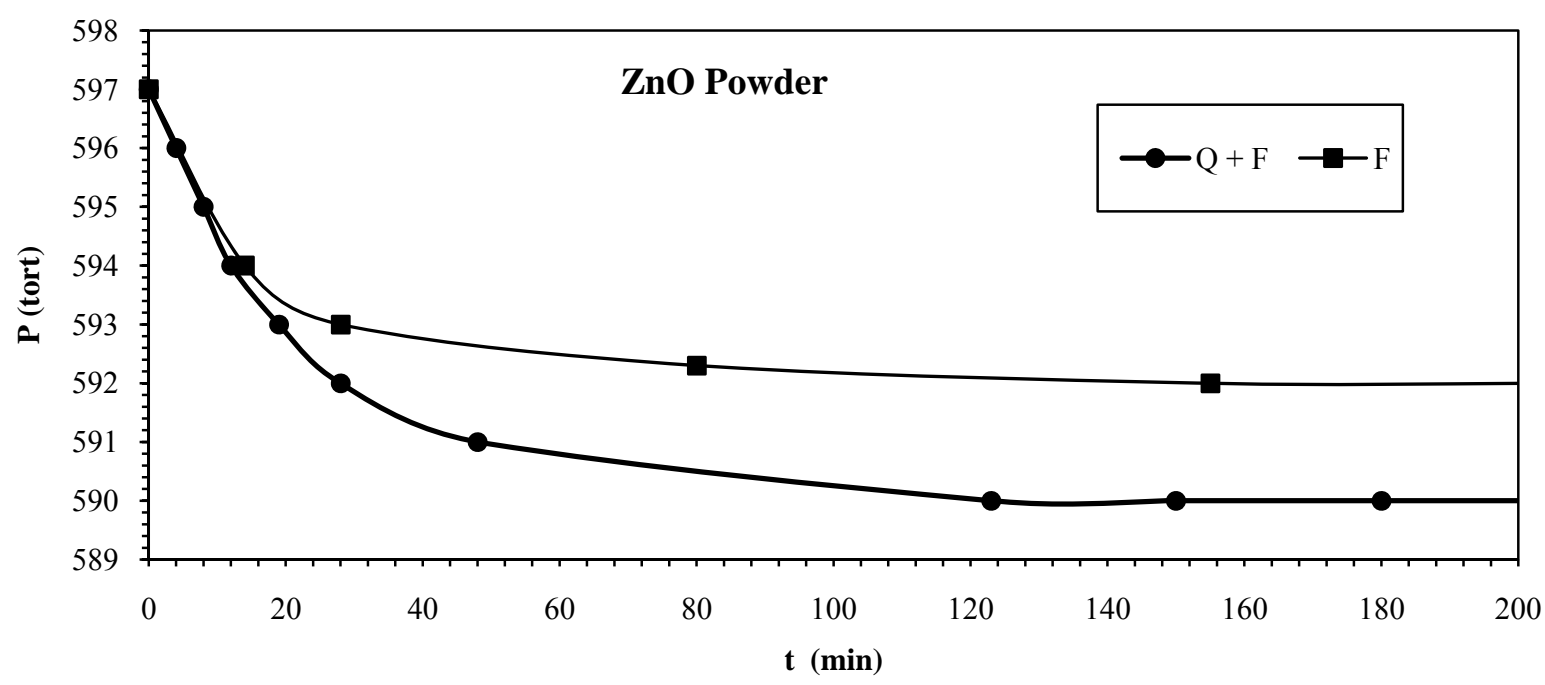

Fig. $11 \mathrm{O}_{2}$ isotherm of the $\mathrm{ZnO}$ powder at $25^{\circ} \mathrm{C}$, chemisorption + physisorption $(\mathrm{F}+\mathrm{Q})$.

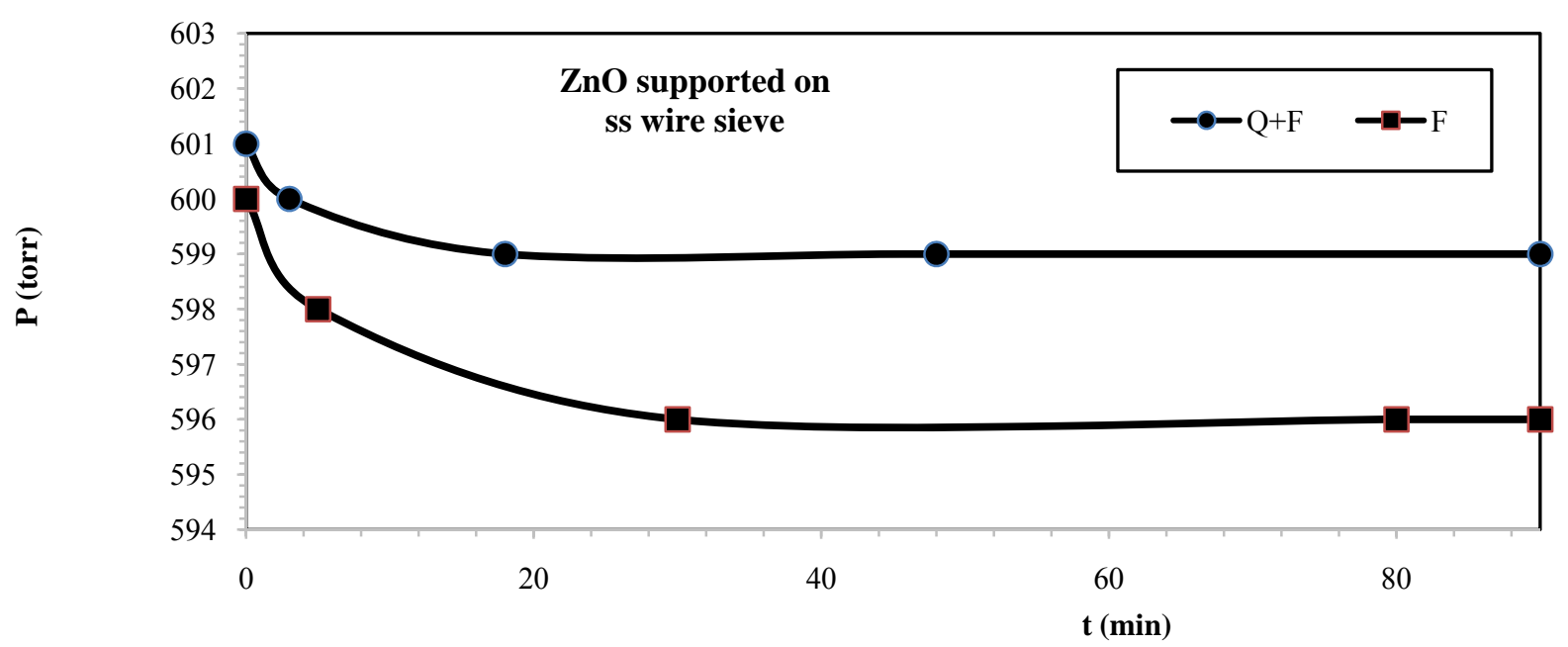

Fig. $12 \mathrm{O}_{2}$ isotherm of the $\mathrm{ZnO}$ supported on SS-wire sieve $\mathrm{M} 4$, at $25^{\circ} \mathrm{C}$, chemisorptions + physisorption $(\mathrm{F}+\mathrm{Q})$. 
Table $1 \mathrm{O}_{2}$ chemisorption for the $\mathrm{ZnO}$ film supported on SS-wire sieves.

\begin{tabular}{lll}
\hline Sample & $\begin{array}{l}\mathrm{ZnO} \text { content } \\
(\%)\end{array}$ & $\begin{array}{l}\mathrm{O}_{2} \text { chemisorption }(\mathrm{O} / \mathrm{ZnO}) \\
(\mathrm{g} \text { atom of oxygen/mol } \mathrm{ZnO})\end{array}$ \\
\hline SS-wire sieve & 0 & 0 \\
ZnO powder & 100 & 0.0189 \\
ZnO supported on SS-wire sieve & 0.2542 & 0.7153 \\
\hline
\end{tabular}

Table 2 Efficiency reduction of CFU Gram negative rod-shaped microbes with UV light and the ZnO film photocatalyst.

\begin{tabular}{|c|c|c|c|c|c|c|c|}
\hline No. & Conditions & $\begin{array}{l}\text { Residence } \\
\text { time (sec) }\end{array}$ & $\begin{array}{l}\text { SS wire sieve } \\
\text { coated with } \\
\mathrm{ZnO} \text { film }\end{array}$ & $\begin{array}{l}\text { Average } \\
\text { UFC/ } 100 \mathrm{~mL} \\
\text { before reactor }\end{array}$ & $\begin{array}{l}\text { Average } \\
\text { UFC/100 mL } \\
\text { after reactor }\end{array}$ & $\begin{array}{l}\text { CFU } \\
\text { destruction } \\
\text { efficiency by } \\
\text { UV (\%) }\end{array}$ & $\begin{array}{l}\text { CFU } \\
\text { destruction } \\
\text { efficiency by } \\
\text { UV plus SS } \\
\text { sieves }\end{array}$ \\
\hline 1 & $\begin{array}{l}\text { Only irradiation with of ultraviolet } \\
\text { light (blank) }\end{array}$ & 7.5 & 0 & 59 & 2.15 & 96.36 & --- \\
\hline 2 & $\begin{array}{l}\text { Irradiation with ultraviolet light plus } \\
\text { coated SS wire sieve with } \mathrm{ZnO} \text { film }\end{array}$ & 7.5 & $\begin{array}{l}3 \\
\left(120 \mathrm{~cm}^{2}\right)\end{array}$ & 61 & 0.67 & & 98.89 \\
\hline 3 & $\begin{array}{l}\text { Irradiation with ultraviolet light plus } \\
\text { coated SS wire sieve with } \mathrm{ZnO} \text { film }\end{array}$ & 7.5 & $\begin{array}{l}5 \\
\left(200 \mathrm{~cm}^{2}\right)\end{array}$ & 57 & 0.58 & & 98.98 \\
\hline 4 & $\begin{array}{l}\text { Only irradiation with of ultraviolet } \\
\text { light(blank) }\end{array}$ & 20 & 0 & 58 & 1.87 & 96.77 & ---- \\
\hline 5 & $\begin{array}{l}\text { Irradiation with ultraviolet light plus } \\
\text { coated SS wire sieve with } \mathrm{ZnO} \text { film }\end{array}$ & 20 & $\begin{array}{l}3 \\
\left(120 \mathrm{~cm}^{2}\right)\end{array}$ & 60 & 0.63 & & 98.93 \\
\hline 6 & $\begin{array}{l}\text { Irradiation with ultraviolet light plus } \\
\text { coated SS wire sieve with } \mathrm{ZnO} \text { film }\end{array}$ & 20 & $\begin{array}{l}5 \\
\left(200 \mathrm{~cm}^{2}\right)\end{array}$ & 63 & 0.21 & & 99.66 \\
\hline
\end{tabular}

Table 3 Photocatalytic efficiency of CFU reduction as function of residence time and number of sieves.

\begin{tabular}{lccc}
\hline \multirow{2}{*}{ Disinfectant material } & \multicolumn{2}{c}{ Residence time (sec) } & Efficiency increment (\%) \\
\cline { 2 - 4 } & 7.5 & 20 & \\
UV & 93.6 & 96.72 & $\mathbf{0 . 0 4}$ \\
UV + 3 ZnO covered sieves & 98.89 & 98.93 & $\mathbf{0 . 6 8}$ \\
UV + 5 ZnO covered sieves & 98.98 & 99.66 & \\
Efficiency increment (\%) & $\mathbf{0 . 0 9}$ & $\mathbf{0 . 7 3}$ & \\
\hline
\end{tabular}

Table 4 Normality test (Shapiro-Wilk) equal variance test: failed $(P<0.050)$, normality test (Shapiro-Wilk) failed (P $<$ 0.050).

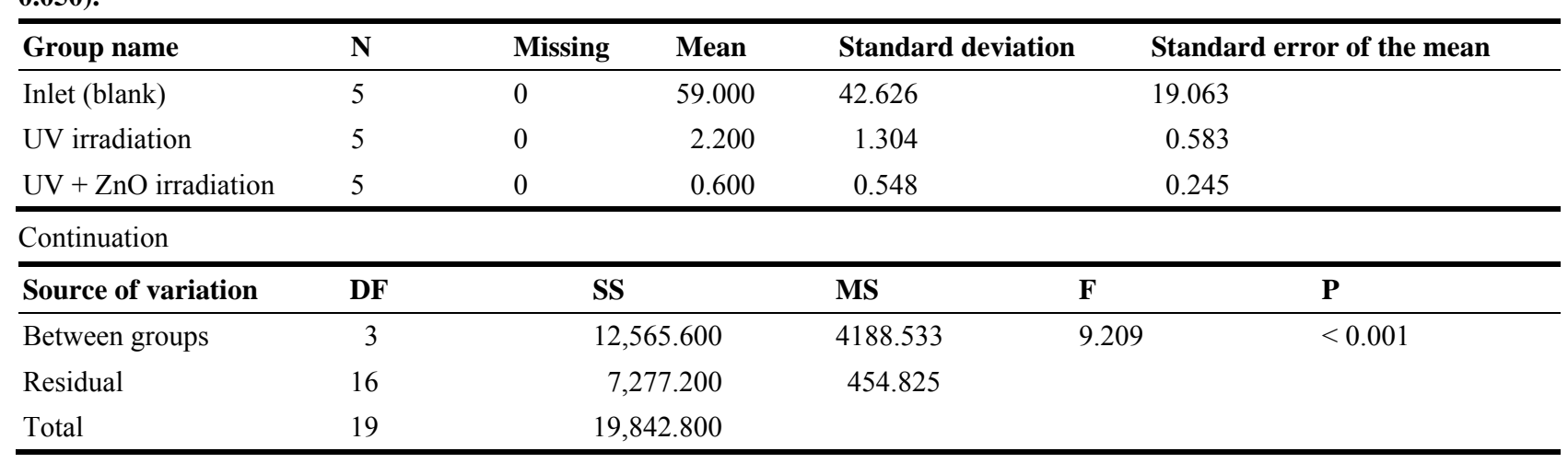

Since the distribution was not normal, it was applied the Kruskal-Wallis test in a range that was applicable to non-parametric data (Table 5).

With the Kruskal-Wallis test, it was confirmed that the differences are significant, since $\mathrm{P}=0.004$ is less than 0.050, and the differences in the median values among the treatment groups are greater than would be expected by chance. 
Table 5 Kruskal-Wallis one way analysis of variance on ranks, normality test (Shapiro-Wilk) failed $(P<0.050)$.

\begin{tabular}{lllccc}
\hline Group & $\mathbf{N}$ & Missing & Median & $\mathbf{2 5 \%}$ & $\mathbf{7 5 \%}$ \\
Inlet (blank) & 5 & 0 & 60.000 & 21.000 & 96.500 \\
UV irradiation & 5 & 0 & 2.000 & 1.000 & 3.500 \\
UV + ZnO irradiation & 5 & 0 & 1.000 & 0.000 & 1.000 \\
\hline
\end{tabular}

$* \mathrm{H}=13.468$ with 2 degrees of freedom and $(\mathrm{P}=0.004)$.

According to these results, the differences between the treatment with UV light and the treatment with $\mathrm{ZnO}$ are significant.

\section{Conclusions}

The following conclusions can be obtained from this study:

(1) With electrophoretic deposition of $\mathrm{Zn}(\mathrm{OH})_{2}$ and a subsequent calcination, the $\mathrm{ZnO}$ film obtained covered the entire sieve with a homogenous morphology, where zincite is present as the ceramic with photocatalytic activity;

(2) The electrophoretic deposition does not require controlled conditions of pressure and temperature, and occur at ambient conditions;

(3) The chemisorption of oxygen shows the presence of active sites where oxidation could occur and are potential sites for photocatalytic activity;

(4) The chemisorption of oxygen on the sieve covered with $\mathrm{ZnO}$ and the $\mathrm{ZnO}$ powder shows that the surface reaction area is higher in the sieve, such condition potentially increase the efficiency in destruction of the microorganism;

(5) $\mathrm{ZnO}$ ceramic possess significant antibacterial properties for this consortium;

(6) The experiment shows that the amount of photocatalytic material contributes more than the residence time to increase the destruction efficiency, and approaches to total destruction when the amount and time increases;

(7) The experiment shows that this technology could be extrapolated to control airborne bacteria in an indoor environment in a short time;

(8) The photocatalytic process is more cost-effective than other technologies actually used with similar bacterial destruction efficiencies, since the former only needs energy to operate and the semiconductor catalyst is inexpensive and capable of mineralising airborne microbes.

\section{Acknowledgements}

This work was supported by the Metropolitan Autonomous University Azcapotzalco Campus and Interdisciplinary Center of Research and Studies on Environmental and Development of the National Poly Technique Institute of Mexico.

\section{References}

[1] Deepali, S., Jaspreet, R., Kaith, B. S., Mohinder, K., and Sapna, S. 2010. "Synthesis of $\mathrm{ZnO}$ Nanoparticles and Study of Their Antibacterial and Antifungal Properties." Thin Solid Films 519 (3): 1224-1229.

[2] Alvarado, A. C., and Predicala, B. Z. 2013. "Control of Growth of Disease-Causing Microorganisms and Greenhouse Gas Emissions from Swine Operations Using Zinc Oxide Nanoparticles." In CSBE/SCGAB 2103 Annual Conference, 13-82.

[3] Saima, S., Rafiuddin Zain Khan, M., and Shahadat, M. 2015. "Development of $\mathrm{ZnO}$ and $\mathrm{ZrO}$ Nanoparticles: Their Photocatalytic and Bactericidal Activity." Journal of Environmental Chemical Engineering 3 (2): 886-891.

[4] Li, Q., Mahendra, S., Lyon, D. Y., Brunet, L., Liga, M. V., and Li, D. et al. 2008. "Antimicrobial Nanomaterials for Water Disinfection and Microbial Control: Potential Applications and Implications." Water Research 42 (18): 4591-4602.

[5] Zhang, L., Jian-Hui, Y., Min-Jie, Z., Yan-Ping, Y., Ye, L., and You-Nian, L. 2014. "Photocatalytic Degradation and Inactivation of Escherichia Coli by $\mathrm{ZnO} / \mathrm{ZnAl}_{2}$." The Chinese Journal of Nonferrous Metals 24 (3): 743-749.

[6] Behnajady, M. A., Modirshahla, N., Daneshvar, N., and Rabbani, M. 2007. "Photocatalytic Degradation of C.I. Acid Red 27 by Immobilised $\mathrm{ZnO}$ on Glass Plates in Continuous-Mode." Journal of Hazardous Materials 140 (1-2): 257-263. 

Antimicrobial Activity Evaluation

[7] Mclaren, A., Valdes-Solis, T., Gouqiang, L., and Shik Chi, T. 2009. "Shape and Size Effects of $\mathrm{ZnO}$ Nanocrystals on Photocatalytic Activity." J. Am. Chem. Soc. 131: 12540-12541.

[8] Padmavathy, N., and Vijayaraghavan, R. 2008. "Enhanced Bioactivity of $\mathrm{ZnO}$ Nanoparticles: An Antimicrobial Study." Sci. Technol. Adv. Mater 9: 1-7.

[9] Gamage, J., and Zhang, Z. 2014. "Antimicrobial and Photocatalytic Disinfection Mechanisms in Silver-Modified Photocatalysts under Dark and Light Conditions." Journal of Photochemistry and Photobiology C: Photochemistry Reviews 19: 62-75.

[10] Gordon, T., Perlstein, B., Houbar O., Felner, I., Banin, E., and Shlomo, M. 2011. "Synthesis and Characterization of Zinc/Iron Oxide Composite Nanoparticles and Their Antibacterial Properties." Colloids and Surfaces: A Physicochemical Engineering Aspects 374: 1-8.

[11] Wang, S., Ang, H. M., and Tade, M. O. 2007. "Volatile Organic Compounds in Indoor Environment and Photocatalytic Oxidation: State of the Art.” Environmental International 33: 694-705.

[12] Pigeot-Remy, S., Simonet, F., Errazuriz-Cerda, E., Lazzaroni, J. C., Atlan, D., and Guillard, C. 2011. "Photocatalysis and Disinfection of Water: Identification of Potential bacterial Targets." Applied Catalysis B Environmental 104 (3-4): 390-398.

[13] Fengna, C. I., Xudong, Y., Henry, K. C., and Chen, D. 2010. "Photocatalytic Oxidation for Antimicrobial Control in Built Environment: A brief literature Review." Building and Environment 45: 1747-1754.

[14] Chong, M. N., Jin, B., Chow, C. W. K., and Saint, C. 2010. "Recent Developments in Photocatalytic Water Treatment Technology: A Review." Water Research 44: 2997-3027.

[15] Reddy, K. M., Feris, K., Bell, J., Wingett, D. G., Hanley, C., and Punnoose, A. 2007. "Selective Toxicity of Zinc Oxide Nanoparticles to Prokaryotic and Eukaryotic Systems." Appl. Phys. Lett. 90: 1-3.

[16] Dalrymple, O. K., Stefanakos, E., Trotz, M. A., and Goswami, D. Y. 2010. "A Review of the Mechanisms and Modelling of Photocatalytic Disinfection." Applied Catalysis B: Environmental 98: 27-38.

[17] Choobineh, A., Rostam, R., and Tabatabae, S. H. 2009. "Assessment of Bioaerosols Types and Concentration in Ambient Air of Shiraz University of Medical Sciences Educational Hospitals in 2008." Iran Occupational Health J. 6 (2): 69-76.

[18] Hwang, S. H., Yoon, Ch, S., Ryu, K. N., Pair, S. Y., and Cho, J. H. 2010. "Assessment of Airborne Environmental Bacteria and Related Factors in 25 Underground Railway Stations in Seoul, Korea." Atmospheric Environment 44 (13): 1658-1662.
[19] Rosas, I., Cravioto, A., and Ezcurra, E. 2004. Microbiologia Ambiental. Mexico: Instituto Nacional Ecologia.

[20] Sudharsanam, S., Swaminathan, S., Ramalingam, A., and Thangavel, G. 2012. "Characterisation of Indoor Bioaerosols from a Hospital Wardina Tropical Setting." African Health Sciences 12 (2): 217-225.

[21] Ghorbani-Shahna, F., Joneidi-Jafari, A., Yousefi-Mashouf, R., Mohseni, M., and Shirazi, J. 2004. "Type and Concentration of Bioaerosols in the Operating Room of Educational Hospitals of Hamadan University of Medical Sciences and Effectiveness of Ventilation Systems, in Year 2004." J. Hamadan Univ. Med. Sci. 13 (2): 64-70.

[22] Pal, A., Min, X., Yu, L., Pehkonen, S. O., and Ray, M. B. 2005. "Photocatalytic Inactivation of Bioaerosols by $\mathrm{TiO}_{2}$ Coated Membrane." International Journal of Chemical Reactor Engineering 3: 1-12.

[23] Hoseinzadeh, E., Samarghandie, M. R., Ghiasian, S. A., Alikhani, M. Y., and Roshanaie, G. 2013. "Evaluation of Bioaerosols in Five Educational Hospital Wards Air in Hamedan, during 2011-2012." Jundishapur Journal of Microbiology 6 (6): e10704.

[24] Jagger, J. 1976. Introduction to Research in Ultraviolet Photobiology. New Jersey: Prentice-Hall Inc..

[25] Sulciute, A., and Valatka, E. 2012. "Electrodeposition and Photoelectro Catalytic Activity of $\mathrm{ZnO}$ Films on AISI 304 Type Steel." Material Science 18 (4): 318-324.

[26] Tan, T. V., Del, Rio, L., Valdes-Solis, T., and Marban, G. 2013. "Stainless Steel Wire Mesh-Supported $\mathrm{ZnO}$ for the Catalytic Photodegradation of Methylene Blue under Ultraviolet Irradiation." Journal of Hazardous Materials 246-247: 126-134.

[27] Yu-Jie, Ch., Jyh-Wei, L., Ching-Hsing, L., Chen-Yu, Ch., Yao-Chuan, L. and Mei-Yin, H. 2010. "Photocatalytic Deactivation of Airborne Microbial Cells by the Stainless Steel Sieves with Surface Coated $\mathrm{TiO}_{2}$ Thin Films." Surface \& Coating Technologies 205: S328-S332.

[28] Mo, J., Zhang, Y., Xu, Q., Lamson, J. J., and Zhao, R. 2009. "Photocatalytic Purification of Volatile Organic in Indoor Air: A Literature Review." Atmospheric Environment 43: 2229-2246.

[29] Zhong, L., and Haghighat, F. 2015. "Photocatalytic Air Cleaners and Material Technologies-Abilitiesand Limitations.” Building and Environment 91: 191-203.

[30] Mahmmodian, M., and Movaheddi, M. A. 2010. "Assessment of Biological Agents in the Air of Different Wards in Imam Khomayni and Shahid Zare Hospitals in Sari, 2007." J. North Khorasan Univ. Med. Sci. 2 (2-3): 51-58.

[31] Lim, T., Cho, J., and Kim, B. S. 2010. "The Predictions of Infection Risk of Indoor Airborne Transmission of 


\section{Antimicrobial Activity Evaluation}

Diseases in High Rise Hospitals: Tracer Gas Simulation.” Energy and Buildings 42 (8): 1172-1181.

[32] Harrison, J., Pickering, C. A., Faragher, E. B., Austwick, P. K., Little, S. A., and Lawton L. 1992. "An investigation of the Relationship between Microbial and Particulate Indoor Air Pollution and the Sick Building
Syndrome.” Respir. Med. 86 (3): 225-35.

[33] Hossein, H. M., and Bahareh, K. 2014. "Application of Impregnation Combustion Method for Fabrication of Nanostructure $\mathrm{CuO} / \mathrm{ZnO}$ Composite Oxide: XED, FESEM, DRS and FTRIR Study." Journal of Industrial and Engineering Chemistry 20 (2): 1566-1570. 